\title{
Komplement C5a-antagonista-terápia hatása nem okklúzív mesenterialis ischaemia állatmodelljeiben
}

\author{
Effects of complement C5a inhibitor therapy in animal models \\ of non-occlusive mesenteric ischemia
}

\author{
NÓGRÁDY MIKLÓS ${ }^{1,2}$, VARGA GABRIELLA ${ }^{1}$, SZÜCS SZILÁRD ${ }^{1}$, KASZAKI JÓZSEF ${ }^{1}$, \\ BOROS MIHÁLY ${ }^{1}$, ÉRCES DÁNIEL ${ }^{1, @}$ \\ Szegedi Tudományegyetem, Szeged \\ ${ }^{1}$ Sebészeti Mütéttani Intézet (igazgató: Dr. Boros Mihály) \\ ${ }^{2}$ Szülészeti és Nőgyógyászati Klinika (igazgató: Dr. Németh Gábor)
}

\begin{abstract}
Bevezetés: A nem okkluzív mesenterialis ischaemia (NOMI) anatómiai okok nélkül alakul ki, korai diagnosztizálása nehéz, terápiája sem megoldott. Modellkísérleteinkben a komplement C5a gátlásán keresztül a komplementaktiváció szerepét vizsgáltuk a kórfolyamatban. Anyagok és módszerek: A NOMI rövid és hosszú távú hemodinamikai és gyulladásos következményeinek jellemzéséhez Sprague-Dawley patkányokban $(n=28) 60$ perces parciális aortaokklúziót (PAO; hasi aorta, truncus coeliacustól proximálisan; arteria femoralis középnyomása: 30-40 Hgmm), míg vietnami törpesertésekben ( $n=19) 60$ perces pericardialis tamponádot (artériás középnyomás: 40-50 Hgmm) hoztunk létre. A PAO, valamint a tamponád 45. percében komplement C5a-gátló kezelést alkalmaztunk (acetil-peptid-A; $4 \mathrm{mg} / \mathrm{kg} i v$.). Az állatokban monitoroztuk a makro- és mikrokeringést, mértük a leukocytainfiltrációt, a gyulladásos mediátorok (endothelin, HMGB-1) plazmaszintjét. Eredmények: Patkányokban a PAO megszüntetése után 24 órával a C5a gátlása csökkentette a szisztémás gyulladásos válasz részeként megemelkedett perctérfogatot (203,1 $\pm 5 \mathrm{vs.} 269,6 \pm 8,1 \mathrm{ml} / \mathrm{min} / \mathrm{kg})$ és arteria mesenterica superior (AMS) áramlását, fokozta az ileum mucosa mikrokeringését (833,5 $\pm 33,8$ vs. 441,9 $\pm 22,4 \mu \mathrm{m} / \mathrm{s})$. Az acetilpeptid-A sertésekben átmenetileg növelte az AMS áramlását és tartósan az ileummucosa-kapillárisáramlást $(648,1 \pm 45,4$ vs. $329,8 \pm 12,6 \mu \mathrm{m} / \mathrm{s}$ ). A kezelt állatoknál alacsonyabb gyulladásos mediátorszintet és szöveti leukocytainfiltrációt mértünk mindkét NOMI-modellben. Következtetések: A komplementaktiváció jelentős szerepet játszik a NOMI alatt bekövetkező makro- és mikrokeringési zavar kialakulásában, a C5a gátlása a gyulladásos folyamat mérséklése mellett befolyásolja a NOMI hemodinamikai következményeit is.
\end{abstract}

Kulcsszavak: vékonybél, komplement C5a, mikrokeringés, endothelin, high mobility group box protein-1

Introduction: Non-occlusive mesenteric ischemia (NOMI) develops without anatomical causes. Early diagnosis is challenging and treatments are of questionable effectiveness. We investigated the role of complement activation in the pathophysiology of NOMI in animal models through the inhibition of complement C5a. Materials and methods: 60-min partial aortic occlusion (PAO; abdominal aorta, proximal to celiac trunk; mean arterial pressure: $30-40 \mathrm{mmHg}$ ) was established in Sprague-Dawley rats $(n=28)$ and 60-min cardiac tamponade in minipigs $(n=19$; mean arterial pressure: $40-50 \mathrm{mmHg}$ ) to observe short- and long-term circulatory and inflammatory consequences of NOMI. Macro- and microhemodynamics, leukocyte infiltration, plasma levels of inflammatory mediators (endothelin, HMGB-1) were measured. C5a inhibitor (Acetyl-Peptid-A; $4 \mathrm{mg} / \mathrm{kg}$ iv) was administered at the 45th min of PAO or tamponade, respectively. Results: Twenty-four hours after PAO systemic inflammatory response increased cardiac output and superior mesenteric artery flow (SMAF). C5a inhibition reduced the elevated cardiac output $(203.1 \pm 5 \mathrm{vs} 269.6 \pm 8.1 \mathrm{ml} / \mathrm{min} / \mathrm{kg})$ and SMAF and increased ileal microcirculation $(833.5 \pm 33.8$ vs $441.9 \pm 22.4 \mu \mathrm{m} / \mathrm{s})$. In pigs, after the tamponade, C5a inhibition reduced the immediate hemodynamic disturbances, temporarily increased SMAF and permanently the ileal microcirculation. The Acetyl-Peptid-A treatment reduced leukocyte infiltration and plasma levels of inflammatory mediators in both NOMI models. Conclusions: Complement activation plays central role in the macro- and microcirculatory disturbance during NOMI. C5a inhibition reduces the inflammatory activation and influences the hemodynamic consequences of experimental NOMI.

Keywords: small intestine, complement C5a, microcirculation, endothelin, high mobility group box protein-1

Beérkezett: 2016. október 4.; elfogadva: 2017. május 15.

@Levelezési cím/Corr. address: Dr. Érces Dániel, Szegedi Tudományegyetem, Általános Orvostudományi Kar, Sebészeti Műtéttani Intézet, 6720 Szeged, Szőkefalvi-Nagy Béla u. 6. Telefon: +36 62545 103; Fax: +36 62545 672;

E-mail: erces.daniel@med.u-szeged.hu 
Rövidítések: AcPepA = acetil-peptid-A; AMS = arteria mesenterica superior; $\mathrm{CO}$ = thermodilutiós perctérfogat; $\mathrm{ET}=$ endothelin; HMGB-1 = high-mobility group box protein-1; HR = szívfrekvencia; MAP = artériás középnyomás; $\mathrm{MPO}=$ mieloperoxidáz; NOMI = nem okkluzív mesenterialis ischaemia; OPS = orthogonalis polarizációs spektrális; $\mathrm{PAO}=$ parciális aortaokklúzió; $\mathrm{PT}=$ pericardialis tamponád; $\mathrm{RBCV}=$ vörösvértestek átlagos áramlási sebessége

\section{Bevezetés}

Nem okkluzív mesenterialis ischaemia (NOMI) az arteria mesenterica superior (AMS) vagy más splanchnicus veröérágak fizikai elzáródásai nélkül alakul ki. Az érintett területen a bélfal károsodása változó mértékü lehet, akár gangraena kialakulása is elöfordulhat. A kórkép magas mortalitású, a jelenlegi terápiás lehetőségek mellett eléri az 50-70\%-ot. ${ }^{1,2}$ Fontos problémát jelent, hogy leggyakrabban nem specifikus tünetek jelentkeznek, nehezen diagnosztizálható, még modern képalkotó eljárások segítségével is, ezért vagy egyáltalán nem, vagy csak a folyamat késői szakaszában kerül felismerésre, amikor a súlyos szövődmények - peritonitis, szepszis - már bekövetkezhettek. ${ }^{1}$ Elsődlegesen ritkán alakul ki, ezekben az esetekben a betegek általában idősek, krónikus szívelégtelenségben szenvednek. Gyakrabban jelentkezik szövődményként alacsony perctérfogattal járó állapotok során, de szívsebészeti beavatkozások alatt az extracorporalis keringés miatt kialakuló gyulladásos reakció és az alkalmazott vazopresszorterápia is hozzájárulhat a NOMI kialakulásához. ${ }^{3}$

A NOMI létrejöttében kiemelkedő jelentőséggel bír az AMS ellátási területén kialakuló reaktív vasoconstrictio. A splanchnicus területre nyugalmi állapotban a perctérfogat 25\%-a esik, ezért amennyiben a létfontosságú szervek (központi idegrendszer, vese, szív) vérellátása csökken, a keringés átszerveződése, redisztribúciója jön létre. Ilyenkor az AMS áramlása lecsökken a rezisztenciaerek vasoconstrictiójának következtében. A feltételezések szerint e folyamatban fontos szerepet játszhat a komplementrendszer aktivációja, különösen a képződő C5a-fragmentum. A komplement C5a simaizom-kontrakciót okoz, amellyel közvetlenül is hozzájárul a mikroperfúzió csökkenéséhez. Mediátorok felszabadulásának (hisztamin, tromboxán-A2) szabályozásán keresztül ugyanakkor közvetett módon is szerepet játszik az egyes szervek vérátáramlásának csökkenésében, ${ }^{4}$ és a szisztémás, artériás hipotenzió kialakulásában is. ${ }^{5}$ Kemotaktikus hatása révén neutrophilgranulocyta-akkumulációt vált ki, citokinek és reaktívoxigén-származékok termelését fokozza, amellyel a gyulladásos folyamat súlyosbodásához is hozzájárul. ${ }^{6-8}$

A komplement C5a szerepét a NOMI kórtanában az acetil-peptid-A (AcPepA) mesterséges, 17 aminosavból álló (ASGAPAPGPAGPLRPMF), szelektív C5a-antagonista peptid segítségével vizsgáltuk. In vitro vizsgálatok igazol- ták, hogy az AcPepA koncentrációfüggő módon kötődik a komplement C5a központi régiójához. ${ }^{9}$ Az AcPepA korábbi kísérletek során hatékonynak bizonyult C5a-dependens endotoxinsokk-modellekben is, ahol jelentősen javította a kezelés nélkül letalis inzultus túlélési arányát. ${ }^{10}$

Nagy klinikai jelentősége ellenére a NOMI-ra vonatkozó ismereteink jórészt esetmegfigyelésekből, valamint az érelzáródással kiváltott (okkluzív, az AMS teljes, mesterséges elzárásával létrehozott) mesenterialis ischaemia állatmodelljeiből gyüjtött adatokból származnak. Utóbbiak azonban csak korlátozottan használhatók a NOMI során kialakuló változások, keringési zavarok kórélettanának megismeréséhez. Mivel a nemzetközi irodalomban nem találtunk megfelelő kisállatmodellt, kidolgoztunk egy eljárást a részleges aortaleszorítással kiváltott NOMI tanulmányozására, patkányokban. E modell alkalmas a NOMI késői hatásainak vizsgálatára is. ${ }^{11}$ Egy további, nagyállatmodellünkben igazoltuk, hogy a pericardialis tamponád által kiváltott változások alkalmasak a NOMI akut hemodinamikai és gyulladásos következményeinek részletes vizsgálatára. ${ }^{12}$

Jelen tanulmányunk célja a komplement C5a kóroki szerepének és a korai gátlás hatékonyságának vizsgálata volt, a NOMI általunk már validált állatkísérletes modelljeinek alkalmazásával, különös figyelemmel a rövid és hoszszú távú hemodinamikai és gyulladásos következményekre.

\section{Anyagok és módszerek}

Kísérleteinkhez 28 hím, Sprague-Dawley patkányt (300 g) és 19 vietnami törpesertést (mindkét nem; $24 \pm 3 \mathrm{~kg}$ ) használtunk. A vizsgálatokat a NIH irányelvei (Guide for the Care and Use of Laboratory Animals) és a tudományos célokra felhasznált állatok védelméről szóló 2010/63 számú EU-direktíva és a 40/2013 (II/14.) kormányrendelet szerint végeztük a Szegedi Tudományegyetem Munkahelyi Állatkísérleti Bizottsága jóváhagyásával (engedélyszám: V/148/2013).

\section{Patkány részleges aortaokklúziója - sebészeti beavatkozások}

A kísérlet 0 . napján nátrium-pentobarbitál anesztéziát (50 mg/kg ip; pentobarbital sodium salt C-II; Sigma-Ald- 
rich Inc, St. Louis, Missouri, Amerikai Egyesült Államok) követően az állatokat hanyatt fekvő helyzetben fütőpadra helyeztük és kanüláltuk a bal oldali arteria femoralist az artériás középnyomás (MAP) és a szívfrekvencia (HR) mérése céljából. Median laparotomiát követően az aorta abdominalis proximális részét kipreparáltuk a rekeszizomtól distalisan és a truncus coeliacus eredésétől proximálisan, majd egy $2 \mathrm{~mm}$ átmérőjű szilikonkatéterből (Silastic Medical Grade Tubing, Dow Corning Corporation, Midland, Michigan, Amerikai Egyesült Államok) kialakított érleszorítót helyeztünk az ér köré. A mütétet követöen 30 perc nyugalmi szakasz következett, amely alatt az állatok intraperitonealis folyadékpótlásban részesültek (Ringer laktát; $10 \mathrm{ml} / \mathrm{kg} / \mathrm{h}$ ). A vizsgálatokat követően a laparotomia sebét két rétegben suturával zártuk. Az arteria femoralisból a kanült eltávolítottuk. Az ér lekötését követően a bemetszés helyén a bőrt Donati szerint zártuk. Ezt követően az anesztéziát megszüntettük, az állatok szoros megfigyelés mellett obszervációs ketrecbe kerültek, ahol ad libitum folyadékot és a posztoperatív 10. óráig táplálékot kaptak. A posztoperatív fájdalom csillapítására $40 \mathrm{mg} / \mathrm{kg}$ dózisban intraperitonealisan adagolt metamizolt (Algopyrin $1 \mathrm{~g} / 2 \mathrm{ml}$ injekció, Sanofi-Aventis Zrt., Budapest, Magyarország) adtunk, szükség esetén (a fájdalom szubjektív tüneteit mutató állatoknál: púpos testtartás, viselkedésmintázat) $20 \mathrm{mg} / \mathrm{kg}$ dózisban egyszeri ismétlést alkalmaztunk (álmütött: $n=2$; PAO: $n=3$; PAO + AcPepA: $n=2$ ).

Az állatokat újra elaltattuk 24 óra elteltével a már leírt módon, majd a spontán légzés megkönnyítésére tracheostomiát hajtottunk végre. A jobb oldali vena jugularist kanüláltuk folyadékpótlás (Ringer laktát infúzió, $10 \mathrm{ml} / \mathrm{kg} / \mathrm{h}$ ) és gyógyszeres kezelés céljából. A MAP és HR mérése céljából kanüláltuk a bal arteria carotis communist. A jobb arteria carotis felöl termisztorkatétert (PTH-01; Experimetria Ltd., Budapest, Magyarország) vezettünk az aorta ascendensbe thermodilutiós perctérfogat $(\mathrm{CO})$ mérése céljából (SPELL Haemosys; Experimetria Kft., Budapest, Magyarország). A median laparotomia sebét újra kinyitottuk, majd a mesenterialis véráramlás mérésére ultrahangos áramlásmérő fejet (Transonic Systems Inc., Ithaca, New York, Amerikai Egyesült Államok) helyeztünk az AMS köré.

\section{Patkány részleges aortaokklúziója - kísérleti csoportok és protokoll}

Az állatokat véletlenszerủen osztottuk három kísérleti csoportba. Az első csoport $(n=8)$ álmütöttként szolgált, míg a második $(n=8)$ és a harmadik $(n=9)$ csoportnál PAO-t váltottunk ki egy órán keresztül, amelynek során a szilikonkatéterből (Silastic Medical Grade Tubing, Dow Corning Corporation, Midland, Michigan, Amerikai Egyesült Államok) kialakított tourniquet részleges megszorításával az arteria femoralisban mért középnyomást 30-40 Hgmm között tartottuk. Az álmütött csoport esetében a mütéti beavatkozások és a kísérleti protokoll megegyezett a másik két cso- portban alkalmazottakkal, azzal a különbséggel, hogy nem került megszorításra az aorta köré vezetett tourniquet. Az első és a második csoportnál az AcPepA vivőanyagát $(1 \mathrm{ml}$ fiziológiás sóoldat) a farokvénába adtuk $i v$., míg a harmadik csoportnál AcPepA-kezelést $(4 \mathrm{mg} / \mathrm{kg} 1 \mathrm{ml}$ fiziológiás sóoldatban $i v$.) alkalmaztunk 15 perccel a PAO vége elött. A kontrollidőpontban (0. perc), 30 perccel a PAO indukciója után (30. perc), közvetlenül a PAO megszüntetése elött (60. perc), valamint a 90. percben mértük a MAP és HR értékeit. A megfigyelési idő leteltével az arteria femoralis katétert eltávolítottuk, a sebet pedig suturával zártuk. Az állatokat azonnal kizártuk a kísérletböl, ha a vizsgálat alatt vagy azt követően az arteria femoralis kanülálásának szövődményeként hátsó végtagi ischaemia kialakulását (cyanosis) vagy a végtag merevségét, mozgásképtelenségét figyeltük meg (PAO: $n=2$; PAO + AcPepA: $n=1$ ). A tartós senyvedés elkerülése érdekében ezekben az esetekben a kísérlet terminálásra került (Na-pentobarbitál; $120 \mathrm{mg} / \mathrm{kg}$ iv; pentobarbital sodium salt C-II; Sigma-Aldrich Inc., St. Louis, Missouri, Amerikai Egyesült Államok).

A PAO-t követő napon, a mütétet követő 30 perc nyugalmi szakasz után, a PAO megszüntetését követő 24. órában minden csoportnál makrohemodinamikai (MAP-, CO-, AMS-áramlás) méréseket végeztünk, valamint $5 \mathrm{~cm}$-re proximálisan a coecumtól a vékonybél-nyálkahártya mikrokeringését orthogonalis polarizációs spektrális (OPS) technikával vizsgáltuk. A vizsgálatokat követően a vena cava inferiorból vérmintákat vettünk HMGB-1 és ET-1 plazmaszint meghatározásához. Szövettani mintákat vettünk az ileumból (coecumtól proximálisan $3 \mathrm{~cm}-\mathrm{re}, 1 \mathrm{~cm}$ hosszúságban kimetszve) a leukocytaakkumuláció szövettani vizsgálatának céljából, majd az állatokat Na-pentobarbitállal $(120 \mathrm{mg} / \mathrm{kg} i v$; pentobarbital sodium salt C-II; Sigma-Aldrich Inc., St. Louis, Missouri, Amerikai Egyesült Államok) túlaltattuk.

\section{Sertés pericardialis tamponádja - sebészi beavatkozások}

A kísérleteket vietnami törpesertéseken végeztük ( $n=19$; $24 \pm 3 \mathrm{~kg}$; mindkét nem), amelyeket a mütétet megelőzően 12 órán át éheztettünk, és vizet ad libitum fogyaszthattak. $\mathrm{Az}$ anesztéziát ketamin $(20 \mathrm{mg} / \mathrm{kg}$; CP-ketamin $10 \%$ injekció A.U.V. 25 ml; Produlab Pharma B.V., Raamsdonksveer, Hollandia) és xylazin ( $2 \mathrm{mg} / \mathrm{kg}$; CP-Xylazin $2 \%$ injekció A.U.V $50 \mathrm{ml}$; Produlab Pharma B.V., Raamsdonksveer, Hollandia) im. kombinációjával indukáltuk, majd fenntartását folyamatos propofolinfúzióval $(50 \mu \mathrm{l} / \mathrm{min} / \mathrm{kg}$; Propofol 2\% MCT/LCT; Fresenius Kabi Deutschland GmbH, Bad Homburg, Németország) végeztük. Altatást követően az állatokat hanyatt fekvő helyzetben fütőpadra helyeztük és a testhőmérsékletüket $36-37{ }^{\circ} \mathrm{C}$ között tartottuk. Az endotrachealis intubációt követően az állatokon mechanikus lélegeztetést alkalmaztunk (Harvard Apparatus, South Natick, Massachusetts, Amerikai Egyesült Államok). A légzési térfogatot $(10 \pm 2 \mathrm{ml} / \mathrm{kg})$ és a légzésszámot úgy ál- 
lítottuk be, hogy a $\mathrm{pCO}_{2}$ értékét vérgázellenőrzés mellett a 35-40 Hgmm-es tartományban tartottuk. A bal oldali arteria femoralist és vena jugularist kanüláltuk a MAP és a CO thermodilutiós (PiCCO Plus, PULSION Medical Systems AG, München, Németország) méréséhez, valamint folyadékpótlás és gyógyszeres kezelés céljából. Az állatok Ringer laktát infúziót kaptak $(10 \mathrm{ml} / \mathrm{kg} / \mathrm{h})$ a kísérlet teljes időtartama alatt. Median laparotomiát követően az AMS gyökét preparáltuk, amely köré a mesenterialis véráramlás mérése céljából ultrahangos áramlásmérő fejet (Transonic Systems Inc., Ithaca, New York, Amerikai Egyesült Államok) helyeztünk. A pericardialis tamponád létrehozása céljából bal oldali lateralis thoracotomia után a pericardiumba dohányzacskóöltésen keresztül vékony kanült (K31 nasogastricus szonda, Laboratori Don Baxter S.p.A., Trieszt, Olaszország) helyeztünk el, majd rögzítettük. A mütét után 30 perc nyugalmi szakasz következett.

\section{Sertés pericardialis tamponádja - kísérleti csoportok és protokoll}

Az állatokat véletlenszerüen három kísérleti csoportba osztottuk. Az első csoport (álmütött, $n=6$ ) kontrollként szolgált. Az álmütött csoport esetében a mütéti beavatkozások és a kísérleti protokoll megegyezett a második $(n=7)$ és harmadik $(n=6)$ csoportnál alkalmazottal, azzal a különbséggel, hogy itt nem hoztunk létre pericardialis tamponádot. A második és harmadik csoportban intrapericardialisan beadott kolloidoldattal $(120 \pm 30 \mathrm{ml} \mathrm{6 \%}$ hidroxi-etil keményítő) pericardialis tamponádot hoztunk létre, mialatt a MAP-ot 40-50 Hgmm között tartottuk. A tamponád 60 percig tartott, majd a folyadék lebocsátását követően az állatokat további 180 percig obszerváltuk. A harmadik csoport a tamponád 45. percében C5a-antagonista (AcPepA-) kezelést kapott ( $4 \mathrm{mg} / \mathrm{kg}$ bolus, $5 \mathrm{ml}$ fiziológiás sóoldatban $i v$. a vena jugularison keresztül). Az AcPepA-t együttmüködő partnerünk állította elő és bocsátotta rendelkezésünkre (Biologica Co. Ltd., Nagoja, Japán). A kontroll és a kezeletlen tamponádos csoportok $0,9 \%$-os NaCl-oldatot kaptak azonos protokoll szerint. A tamponád kezdete jelöli a 0 . percet, vérmintákat vettünk a kontrollperiódusban (-90. és 0 . perc), valamint a 75., 150. és 240. percekben, amelyekből meghatároztuk a HMGB-1- és a big-ET-szintet. Hemodinamikai monitorozást folyamatosan végeztük. A kísérlet minden 30. percében thermodilutiós perctérfogat mérése és a hemodinamikai adatok rögzítése történt. Az ileum mucosa mikrokeringését a coecumtól proximálisan 5,10 , illetve $15 \mathrm{~cm}$-re vizsgáltuk három időpontban (-30. perc, 60. perc, 240. perc). A kísérletek végén vékonybél-biopsziát vettünk az ileumból az MPO-aktivitás mérésére. (A coecumtól proximálisan $20 \mathrm{~cm}-\mathrm{re}$, az antimesenterialis oldal felöl $2 \mathrm{~cm}$ legnagyobb szélességben, ék alakban kimetszve.) A mintavételeket követően az állatokat Na-pentobarbitál adásával túlaltattuk $(120 \mathrm{mg} / \mathrm{kg}$ $i v$.; pentobarbital sodium salt C-II; Sigma-Aldrich Inc., St. Louis, Missouri, Amerikai Egyesült Államok).

\section{Hemodinamikai mérőmódszerek}

Patkányok esetében a MAP-, a CO-, HR- és az AMS-áramlás értékeit számítógépes adatgyüjtő rendszerrel (SPELL Haemosys; Experimetria Kft., Budapest, Magyarország) rögzítettük. A sertések monitorozása során a MAP, a CO és a HR adatainak mérésére PICCO Plus (PULSION Medical Systems AG, München, Németország) rendszert használtunk, az AMS-áramlást számítógépes mérőrendszerrel vizsgáltuk (SPELL Haemosys; Experimetria Kft., Budapest, Magyarország).

\section{A mikrokeringés funkcionális és strukturális vizsgálata képalkotó módszerrel}

Mind a sertés-, mind a patkánymodellben a vékonybél-nyálkahártya mikrokeringésének vizsgálata OPS-technikával történt (Cytoscan A/R, Cytometrics, Philadelphia, Pennsylvania, Amerikai Egyesült Államok), amellyel a nyálkahártya felszíni $200 \mu \mathrm{m}$-es mélységében levő kapillárisokban keringő vörösvértestek tehetők láthatóvá kontrasztanyag alkalmazása nélkül. ${ }^{13} \mathrm{Az}$ ileum megnyitását követően a nyálkahártya mikrokeringéséről vizsgálatonként három darab látótérről, egyenként $30 \mathrm{~s}$ hosszúságú S-VHS videofelvétel készült (Panasonic AG-TL 700, Matsushita Electric Ind. Co. Ltd., Oszaka, Japán), amelyeket off-line analizáltunk (IVM Pictron, Budapest, Magyarország) és meghatároztuk a vörösvértestek átlagos áramlási sebességét (RBCV; $\mu \mathrm{m} / \mathrm{s})$.

\section{Vazoaktív és gyulladásos mediátorok plazmaszintjének meghatározása}

Sertések esetében a vena jugularisból, míg patkányok esetében a vena cava inferiorból 5 ml-nyi vérmintákat vettünk EDTA-t tartalmazó polipropilén csövekbe, majd $1200 \mathrm{G}-\mathrm{vel}$ $4 \mathrm{C}^{\circ}$-on 15 percig centrifugáltuk (Hettich Universal $32 \mathrm{R}$, Hettich Zentrifugen, Tuttlingen, Németország). A plazmamintákat felhasználásig $-70 \mathrm{C}^{\circ}$-on tároltunk. A big endothelin (big-ET; sertések esetén) és az endothelin-1 (ET-1; patkányok) plazmakoncentrációit ELISA-módszerrel (Big-endothelin ELISA és Endothelin ELISA, Biomedica Medizinprodukte $\mathrm{GmbH}$, Bécs, Ausztria) határoztuk meg. A high-mobility group box protein-1 (HMGB-1) plazmakoncentráció mérésére nagy szenzitivitású és specificitású lépcsős szendvics ELISA-módszert használtunk (HMGB-1 ELISA Kit II, Shino-Test Corporation, Kanagawa, Japán).

\section{Fehérvérsejt-infiltráció meghatározása}

Patkányok esetében a fehérvérsejt-infiltrációt szövettani vizsgálattal határoztuk meg. A PAO-t követő napon, a kísér- 
letek végén az ileumból teljes vastagságú szövetmintákat vettünk minden csoportban, amelyeket $6 \%$-os formalinban fixáltuk, paraffinba ágyaztuk és belölük $4 \mu \mathrm{m}$ vastag metszeteket készítettünk. Hematoxilin-eozin festést követően az ileum nyálkahártyáját infiltráló leukocyták számlálását 400-szoros nagyításon végeztük. A számolást vak módszerrel ugyanaz a személy végezte (Sz. Sz.).

A sertések terminális ileumából származó szövetminták mieloperoxidáz (MPO) enzimaktivitása, a szövetbe akkumulálódott neutrophilgranulocyta-aktivációt jellemzi, amelyet Kübler módszere alapján határoztunk meg. ${ }^{14} \mathrm{Az}$ MPO enzimaktivitását a minta fehérjetartalmára vonatkoztatva adtuk meg.

\section{Statisztikai analízis}

Az adatok kiértékelését statisztikai szoftvercsomag segítségével végeztük (SigmaStat for Windows, Jandel Scientific, Németország), nemparametriás módszereket alkalmazva.
A csoporton belüli eltéréseket Friedman-próbával vizsgáltuk, ezen belül a kontrollértéktől való eltérést Dunn-próbával teszteltük. A csoportok közötti különbségek meghatározása Kruskal-Wallis- és Dunn-próbával történt. A grafikonokon a medián értéket és az interkvartilis fél terjedelmet ábrázoltuk. A szignifikanciaszintet $p<0,05$-nál határoztuk meg.

\section{Eredmények}

\section{Hemodinamikai változások}

A patkányokon végzett kísérleteink során a PAO alatt a MAP-ot egy órán keresztül 30 és 40 Hgmm közti értékeken tartottuk. 30 perccel a PAO vége után a MAP szignifikánsan magasabb értéket ért el az álmütött csoporthoz képest. Az AcPepA-kezelés nem befolyásolta ezeket az értékeket és az álmütött csoporton belül sem alakult ki jelentős változás az első napon (1A. ábra).

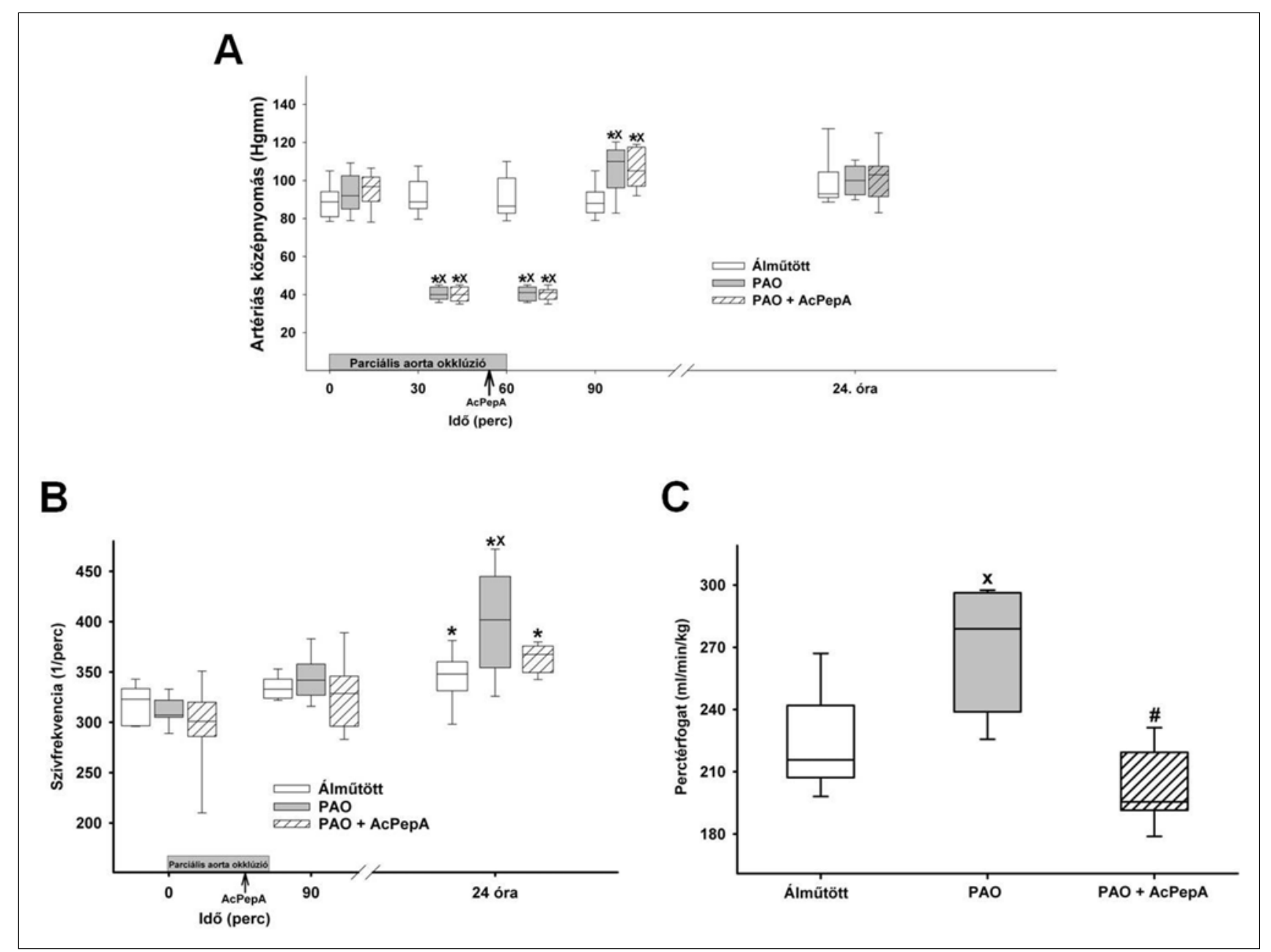

1. ábra. Az artériás középnyomás (A), a szívfrekvencia (B) változásai és perctérfogatértékek (C; 24 órával a parciális aortaokklúzió megszüntetését követően) patkányban az álmütött (fehér oszlop), a parciális aortaokklúziós (PAO; szürke oszlop) és a PAO + AcPepA (sávozott fehér oszlop) csoportokban. Az oszlopgrafikonon a medián értéket és a szórás jellemzésére a 25 és 75 percentilis értékeket tüntettük fel. ${ }^{*} p<0,05$ csoporton belüli szignifikáns változást mutatja a kontrollértékhez képest; ${ }^{\mathrm{x}} p<0,05$ az álmütött csoporthoz képest; ${ }^{\#} p<0,05$ PAO + AcPepA csoport szignifikáns változása a PAO-csoporthoz képest 


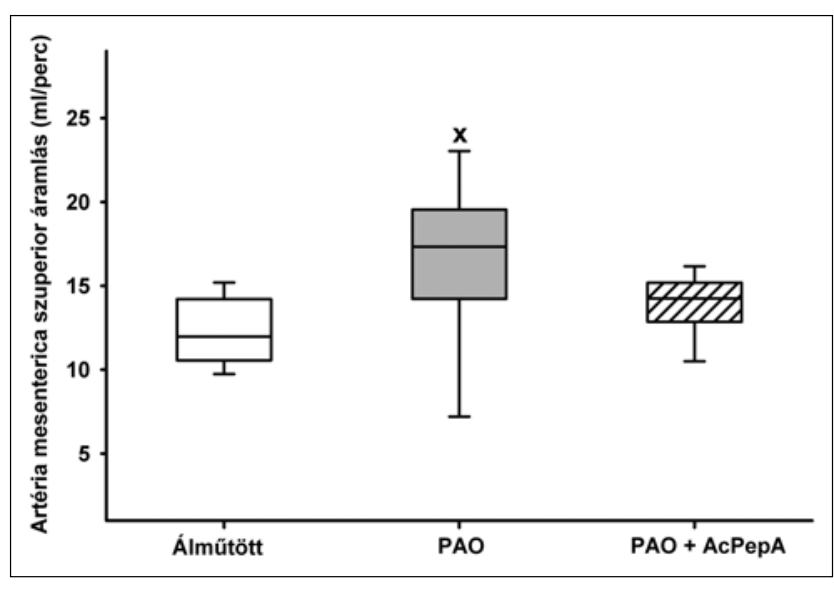

2. ábra. Az arteria mesenterica superior véráramlása patkányban, az álmütött (fehér oszlop), a parciális aortaokklúziós (PAO; szürke oszlop) és a PAO + AcPepA (sávozott fehér oszlop) csoportokban 24 órával a PAO megszüntetését követően. Az oszlopgrafikonon a medián értéket és a szórás jellemzésére a 25 és 75 percentilis értékeket tüntettük fel. ${ }^{\mathrm{x}} p<0,05$ az álmütött csoporthoz képest
Huszonnégy órával a PAO megszüntetését követően, a MAP-értékekben nem volt szignifikáns különbség a kontrollértékekhez képest és a csoportok között. A mütéti beavatkozás fokozott HR-t eredményezett a második napra, azonban a pulzusszám a PAO-n átesett állatok esetében még az álműtött állatok megemelkedett értékeihez képest is szignifikánsan magasabb volt. Az AcPepA-kezelésen átesett állatokban a HR emelkedése nem ért el szignifikáns mértéket az álmütöttekhez viszonyítva ( $1 B$. ábra). A kezelt csoportoknál az AMS-áramlás nem változott a kontrollértékekhez képest. A kezeletlen csoport esetében ugyanakkor jelentős AMS-áramlásemelkedés volt megfigyelhető az álmütött csoporthoz képest (2. ábra). A C5a-gátló kezelés szignifikánsan csökkentette az emelke$\operatorname{dett}$ CO-t (1C. ábra).

Akut pericardialis tamponád sertésmodellünk esetében a hemodinamikai értékeket PiCCO monitorral regisztráltuk. A tamponád alatt, 1 órán át 40-50 Hgmm között tartottuk a MAP-ot, amely időszak alatt a CO 65\%-kal csökkent,

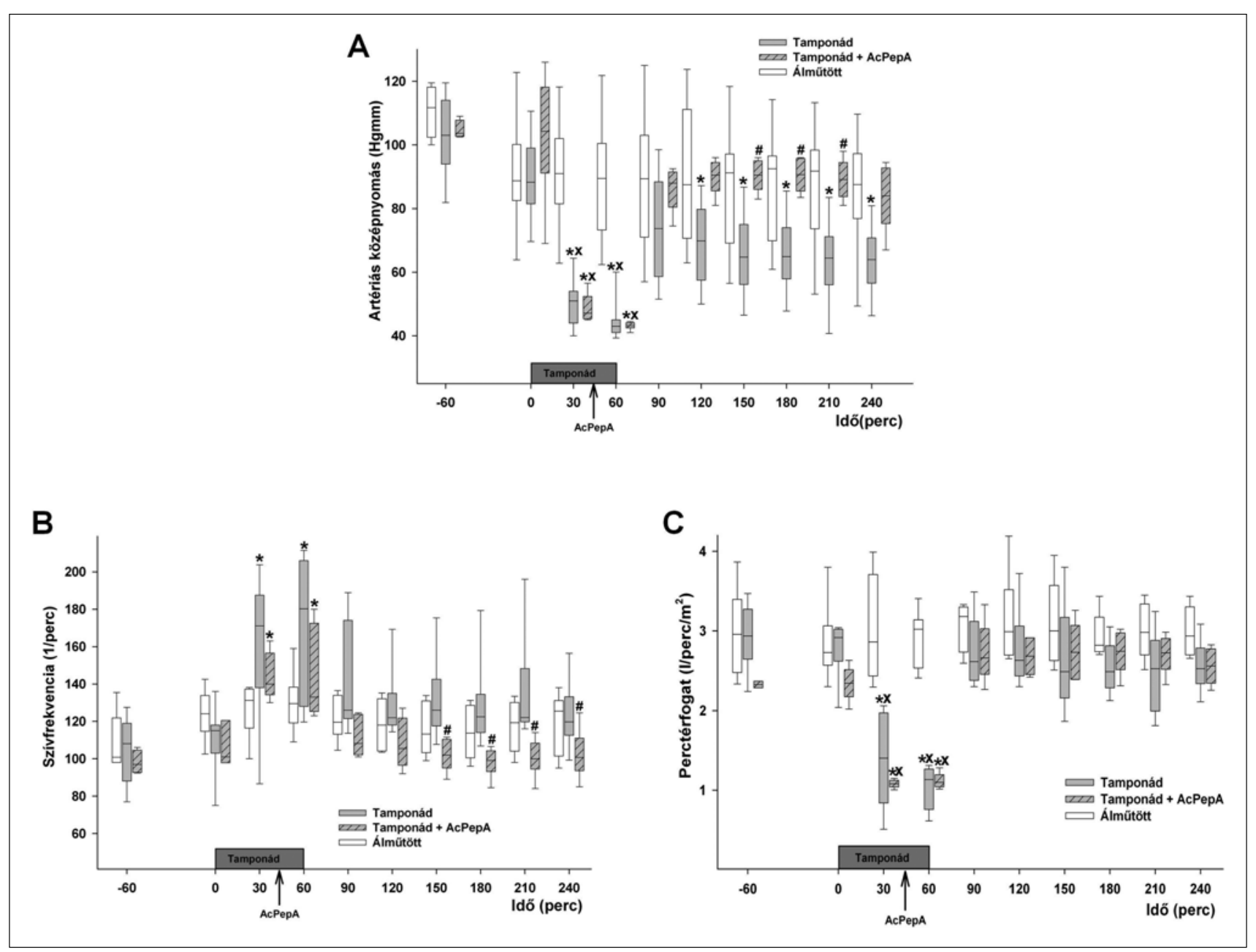

3. ábra. Az artériás középnyomás (A), a szívfrekvencia (B) és a perctérfogat (C) változásai sertésekben, az álmütött (fehér oszlop), a pericardialis tamponád (PT; szürke oszlop) és a PT + AcPepA (sávozott szürke oszlop) csoportokban. Az oszlopgrafikonon a medián értéket és a szórás jellemzésére a 25 és 75 percentilis értékeket tüntettük fel. ${ }^{*} p<0,05$ csoporton belüli szignifikáns változást mutatja a kontrollértékhez képest; ${ }^{\mathrm{x}} p<0,05$ az álmütött csoporthoz képest; ${ }^{\#} p<0,05 \mathrm{PT}+\mathrm{AcPepA}$ csoport szignifikáns változása a PTcsoporthoz képest 


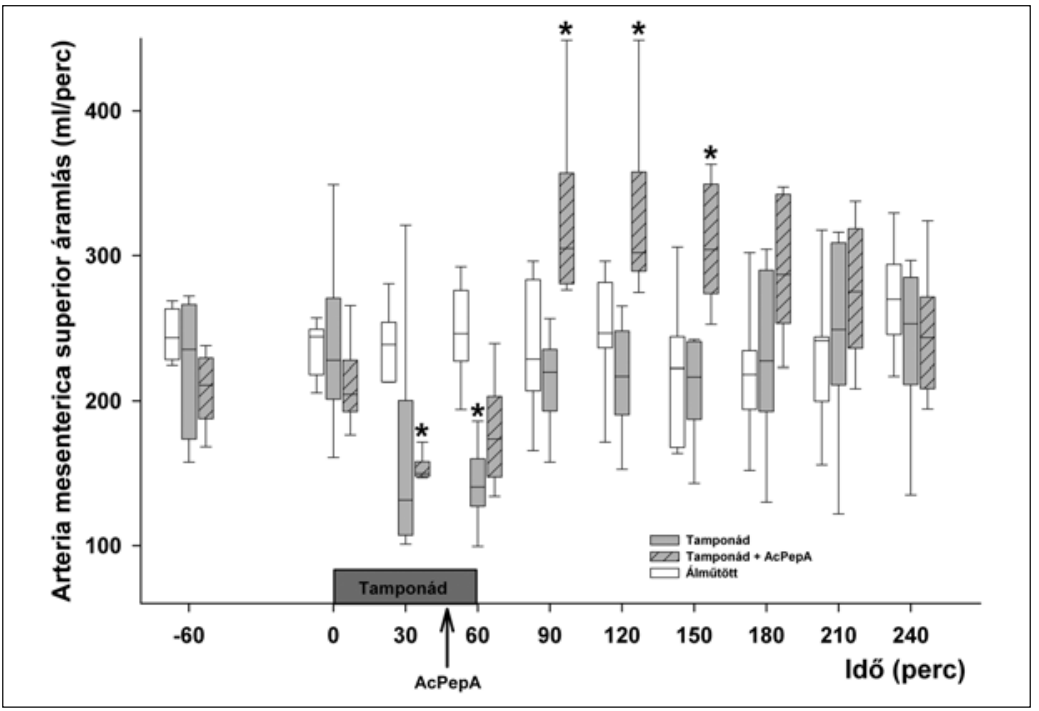

4. ábra. Az arteria mesenterica superior véráramlásának változásai sertésekben, az álmütött (fehér oszlop), a pericardialis tamponád (PT; szürke oszlop) és a PT + AcPepA (sávozott szürke oszlop) csoportokban. Az oszlopgrafikonon a medián értéket és a szórás jellemzésére a 25 és 75 percentilis értékeket tüntettük fel. $* p<0,05$ csoporton belüli szignifikáns változás mutatja a kontrollértékhez képest

jelentős HR-emelkedéssel. A tamponád megszüntetését követően a perctérfogat és a szívfrekvencia is normalizálódott a MAP jelentős csökkenése ellenére $(3 A-C$. ábra).

A csökkenő $\mathrm{CO}$ eredményeként kialakuló redisztribúciót jelezte a szignifikánsan csökkent AMS-áramlás, amely a pericardialis folyadék eltávolítását követően visszatért a kiindulási tartományba (4. ábra).

A komplement C5a-gátló AcPepA-kezelés hatására a CO rendeződése mellett a MAP elérte a kontrollértéket a tamponádot követő időszak alatt. A HR jelentősen csök- kent, amelyet az AMS áramlásának emelkedése kísért ( $3 A-$ C. és 4. ábra).

\section{Változások a biokémiai paraméterekben}

PAO után 24 órával szignifikánsan megemelkedett a gyulladásos mediátor HMGB-1 koncentrációja, amelyet a C5a-gátló kezelés csökkentett. Az ET-1 szintje szintén emelkedett, amit az AcPepA-kezelés szignifikánsan csökkentett (1. táblázat).

1. táblázat. A parciális aortaokklúzió (PAO) és a komplement C5a-gátló AcPepA-kezelés hatása a plazmaendothelin- és -HMGB-1-szintre patkányokban 24 órával a PAO megszüntetését követően

\begin{tabular}{lcccc}
\hline & & Álmütött & PAO & PAO + AcPepA \\
\cline { 3 - 5 } Endothelin & Medián & 5,77 & $8,9^{\mathrm{x}}$ & $5,23^{\#}$ \\
$(\mathrm{fmol} / \mathrm{ml})$ & $25 \mathrm{p} ; 75 \mathrm{p}$ & 5,$11 ; 6,1$ & 8,$34 ; 9,87$ & 3,$8 ; 5,8$ \\
\hline HMGB-1 & Medián & 0,66 & $2,84^{\mathrm{x}}$ & $0,89^{\#}$ \\
$(\mathrm{ng} / \mathrm{ml})$ & $25 \mathrm{p} ; 75 \mathrm{p}$ & 0,$24 ; 0,87$ & 2,$68 ; 3,23$ & 0,$17 ; 1,96$ \\
\hline
\end{tabular}

${ }^{\mathrm{x}} p<0,05$ szignifikáns eltérés az álmütött csoporthoz képest.

${ }^{\#} p<0,05 \mathrm{PAO}+$ AcPepA csoport szignifikáns változása a PAO-csoporthoz képest.

2. táblázat. A pericardialis tamponád (PT) és a komplement C5a-gátló AcPepA-kezelés hatása a plazma bigendothelin- és HMGB-1-szintre sertésekben

\begin{tabular}{lcccccc}
\hline & & -90. perc & 0. perc & 75. perc & 150. perc & 240. perc \\
\cline { 3 - 7 } & \multicolumn{4}{c}{ Big-endothelin-szint $(\mathrm{fmol} / \mathrm{ml})$} & & \\
\hline \multirow{2}{*}{ PT } & Medián & 0,21 & 2,11 & $4,54 *$ * & 5 *x & $4,8^{* \mathrm{x}}$ \\
& $25 \mathrm{p} ; 75 \mathrm{p}$ & 0,$02 ; 0,4$ & 1,$03 ; 3,67$ & 3,$8 ; 5,7$ & 4,$03 ; 5,5$ & 2,$66 ; 5,35$ \\
\hline \multirow{2}{*}{ PT + AcPepA } & Medián & 0,05 & 0,81 & $0,93^{\#}$ & $1,08^{\#}$ & $1,17^{\#}$ \\
& $25 \mathrm{p} ; 75 \mathrm{p}$ & 0,$04 ; 0,07$ & 0,$48 ; 0,87$ & 0,$14 ; 1,11$ & 0,$4 ; 1,38$ & 0,$77 ; 1,44$ \\
\hline \multirow{2}{*}{ Álmütött } & Medián & 0,01 & 1,136 & 0,99 & 0,77 & 0,95 \\
& $25 \mathrm{p} ; 75 \mathrm{p}$ & $0 ; 0,011$ & 0,$3 ; 1,98$ & 0,$31 ; 1,68$ & 0,$35 ; 1,19$ & 0,$31 ; 1,58$ \\
\hline
\end{tabular}


2. táblázat. A pericardialis tamponád (PT) és a komplement C5a-gátló AcPepA-kezelés hatása a plazma bigendothelin- és HMGB-1-szintre sertésekben (folyt.)

\begin{tabular}{lcccccc}
\hline & & -90. perc & 0. perc & 75. perc & 150. perc & 240. perc \\
\cline { 3 - 7 } & & \multicolumn{3}{c}{ HMGB-1 szint $(\mathrm{ng} / \mathrm{ml})$} \\
\hline \multirow{2}{*}{ PT } & Medián & 1,28 & 2,04 & $3,7 * \mathrm{x}$ & $3,5 * \mathrm{x}$ & $4,8^{* \mathrm{x}}$ \\
& $25 \mathrm{p} ; 75 \mathrm{p}$ & 0,$2 ; 2,7$ & 1,$34 ; 2,98$ & 3,$25 ; 4,4$ & 2,$8 ; 5,5$ & 3,$2 ; 5,6$ \\
\hline \multirow{2}{*}{ PT + AcPepA } & Medián & 0,25 & 0,82 & $1,49^{\#}$ & $1,36^{\#}$ & $1,76^{\#}$ \\
& 25 p; 75 p & 0,$08 ; 0,77$ & 0,$53 ; 1,57$ & 0,$98 ; 2,48$ & $0794 ; 2,7$ & 1,$19 ; 3,02$ \\
\hline \multirow{2}{*}{ Álmütött } & Medián & 0,78 & 1,95 & 1,29 & 1,34 & 1,25 \\
& 25 p; 75 p & 0,$01 ; 1,41$ & 1,$03 ; 2,43$ & 0,$95 ; 1,62$ & 1,$03 ; 1,64$ & 1,$0 ; 1,5$ \\
\hline
\end{tabular}

$* p<0,05$ csoporton belüli szignifikáns változás a kontrollértékhez képest.

${ }^{\mathrm{x}} p<0,05$ szignifikáns eltérés az álmütött csoporthoz képest.

${ }^{\#} p<0,05 \mathrm{PT}+\mathrm{AcPepA}$ csoport szignifikáns változása a PT-csoporthoz képest.

Sertés pericardialis tamponádja során az ET-1 stabil prekurzor big-ET jelentősen, négy-ötszörösére emelkedett a C5a-gátló kezelést nem kapott csoportban a tamponádot követően. Jelentős emelkedés volt megfigyelhető a HMGB-1 szintjében is (2. táblázat).

\section{Szöveti leukocytainfiltráció}

Patkányokban a PAO megszüntetését követően 24 órával az ileumból vett szövetmintákban szignifikánsan emelkedett fehérvérsejt-infiltráció volt megfigyelhető a PAO-n átesett
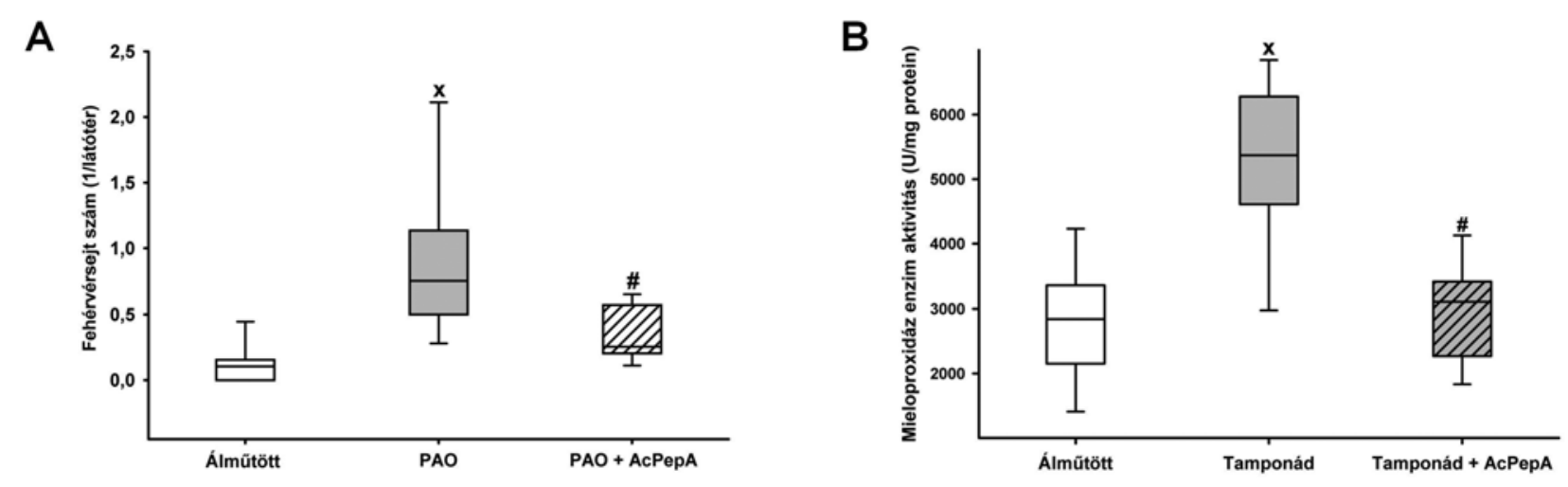

5. ábra. A szöveti leukocytainfiltráció mértéke patkányban (A) az álmütött (fehér oszlop), a parciális aortaokklúziós (PAO; szürke oszlop) és a PAO + AcPepA (sávozott fehér oszlop) csoportokban 24 órával a PAO megszüntetését követően. Sertésileumban mért szöveti mieloperoxidáz enzimaktivitás (B) változásai az álmütött (fehér oszlop), a pericardialis tamponád (PT; szürke oszlop) és a PT + AcPepA (sávozott szürke oszlop) csoportokban. Az oszlopgrafikonon a medián értéket és a szórás jellemzésére a 25 és 75 percentilis értékeket tüntettük fel. * $p<0,05$ csoporton belüli szignifikáns változást mutatja a kontrollértékhez képest; ${ }^{\mathrm{x}} p<0,05$ az álmütött csoporthoz képest; ${ }^{\#} p<0,05$ PT + AcPepA csoport szignifikáns változása a PT-csoporthoz képest

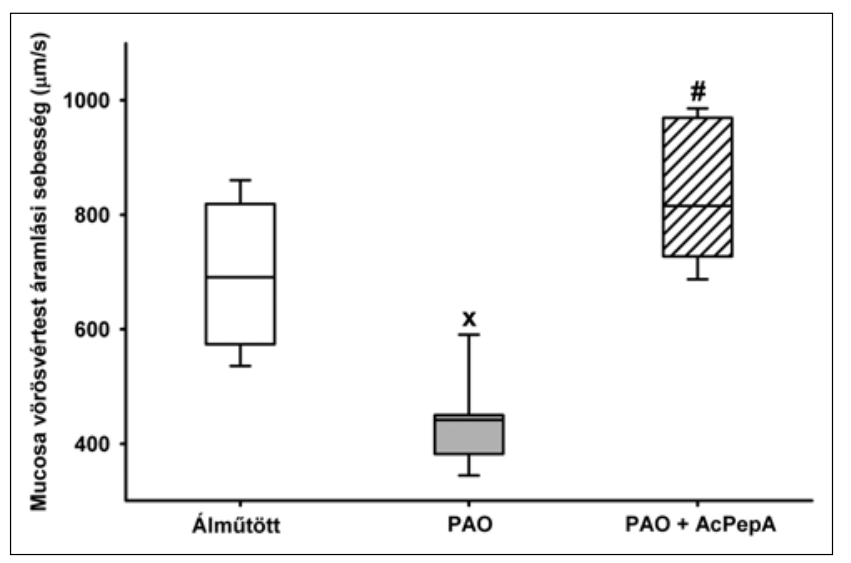

6. ábra. A patkány vékonybélmucosájában mért átlagos vörösvérsejt-áramlási sebesség változásai az álmütött (fehér oszlop), a parciális aortaokklúziós (PAO; szürke oszlop) és a PAO + AcPepA (sávozott fehér oszlop) csoportokban 24 órával a PAO megszüntetését követően. Az oszlopgrafikonon a medián értéket és a szórás jellemzésére a 25 és 75 percentilis értékeket tüntettük fel. ${ }^{\mathrm{x}} p<0,05$ az álmütött csoporthoz képest; ${ }^{\#} p<0,05$ PAO + AcPepA csoport szignifikáns változása a PAO-csoporthoz képest 
csoportnál az álmütött csoporthoz képest. Az AcPepAkezelés szignifikánsan csökkentette a fehérvérsejtes beszürődés mértékét a vékonybélfalban $(5 A$. ábra).

Sertések esetében a tamponádot kísérő NOMI következtében az ileum nyálkahártyáját érintő gyulladás alakult ki, amelyet a szövetek között akkumulálódó fehérvérsejtek mennyiségét jellemző szöveti MPO-enzim aktivitásának emelkedése is igazolt. Az AcPepA-kezelés hatására a szöveti MPO-aktivitás jelentösen csökkent ( $5 B$. ábra).

\section{A vékonybél-nyálkahártya mikrokeringési változásai}

Patkányok esetében a PAO megszüntetése utáni 24. órában a nyálkahártya mikrokeringését az OPS-felvételek alapján szignifikánsan csökkent átlagos RBCV jellemezte az áloperált csoporthoz képest. Az AcPepA-kezelés hatására a vékonybél-nyálkahártya $\mathrm{RBCV}$-értékei a mikrokeringés jelentős javulását mutatták 24 órával az inzultust követően (6. ábra).

A NOMI következtében kialakult akut mikrokeringési változásokat a sertés pericardialistamponád-modelljében tudtuk vizsgálni. Az átlagos RBCV-ben egyértelmü különbség alakult ki a kísérlet végére az AcPepA-kezelés hatására, a mikrokeringés mind a kontrollértékhez, mind a kezelést nem kapott csoporthoz képest is szignifikánsan felgyorsult (7. ábra).

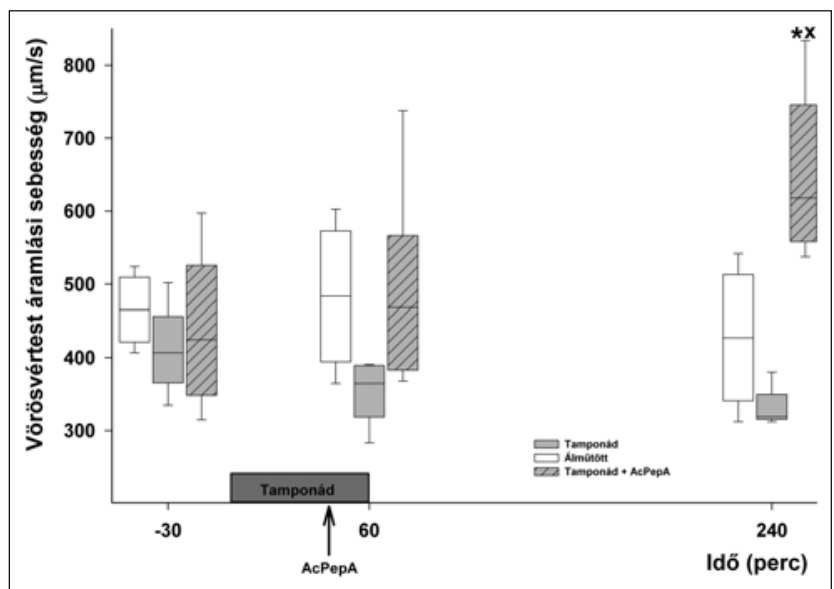

7. ábra. A sertés vékonybélmucosájában mért átlagos vörösvérsejt-áramlási sebesség változásai az álmütött (fehér oszlop), a pericardialis tamponád (PT; szürke oszlop) és a PT + AcPepA (sávozott szürke oszlop) csoportokban. Az oszlopgrafikonon a medián értéket és a szórás jellemzésére a 25 és 75 percentilis értékeket tüntettük fel. $* p<0,05$ csoporton belüli szignifikáns változást mutatja a kontrollértékhez képest; ${ }^{\mathrm{x}} p<0,05 \mathrm{az}$ álmütött csoporthoz képest

\section{Megbeszélés}

Sertéseken végzett vizsgálatainkban a NOMI során létrejövő korai, akut hemodinamikai változásokat figyeltük meg. A tamponádot követően a makrohemodinamikai paraméterek közül a csökkent MAP, valamint a szignifikánsan emelkedő HR volt a meghatározó. E változásokat kifejezett gyulladásos folyamat kísérte, amely során vazoaktív és proinflammációs mediátorok szabadultak fel. A szisztémás keringéssel párhuzamosan a splanchnicus terület mikrokeringése is romlott, amelyet a szöveti MPO-aktivitás növekedése kísért, jelezve ezzel a neutrophilleukocyta-akkumulációt. ${ }^{15,16}$

A tamponád megszüntetését követően a MAP csökkent, de a CO kompenzált volt, és nem volt különbség a kontrollcsoporthoz képest. Ez a megnövekedett HR-nek volt köszönhetö, amely a szívizom fokozott terhelésére utal. Az AcPepA-kezelést követően a MAP a kontrollértékek szintjére emelkedett a CO-hoz hasonlóan, azonban a HR emelkedése nem volt megfigyelhető. Utóbbi változás jelentősége igen fontos, ha figyelembe vesszük azt a tényt, hogy a szívizom keringése a diasztolés fázis alatt biztosított, a szisztolé alatt pedig majdnem teljesen megáll. Az alacsonyabb HR mellett megtartott CO-nál jobb a szívizom oxigénellátása. Elképzelhető, hogy ezeket a változásokat a csökkent ET-felszabadulás eredményezte az AcPepA-kezelés után. Kimutatták, hogy a nem szelektív ET-receptor-antagonista fokozza a CO-t és csökkenti a perifériás ellenállást szívelégtelenségben szenvedő betegeknél. ${ }^{17} \mathrm{Az}$ AMS-áramlás a tamponád alatt lecsökkent, jelezve ezzel az ellátási terület vérellátásának csökkenését, azonban a tamponádot követően az áramlás visszatért a kontrollértékekre és nem volt szignifikáns különbség az álmütött csoporthoz képest. A kezelt csoportnál az AMS-áramlás szignifikánsan emelkedett a tamponádot követően, majd fokozatosan visszaállt a kontrollértékekre a kísérlet végéig. Ez a korai áramlásemelkedés feltehetően a vasoconstrictor ET-1 relatív hiányának is köszönhető. Ezt támasztja alá, hogy korábbi vizsgálatok igazolták, hogy hasonló körülmények között az ET-A receptor gátlása képes javítani a zsigeri keringést. ${ }^{18}$

A késői hemodinamikai változásokat patkányokon végzett kísérleteink során figyeltük meg, ezek hasonlóak voltak a szisztémás gyulladásos válaszban leírt változásokhoz, amely miatt lényeges különbségeket figyeltünk meg a sertésekben mért akut változásokhoz képest. A NOMI indukcióját követő napon, annak ellenére, hogy a MAP a normáltartományban volt, a HR és a CO szignifikánsan megemelkedett. Ez kompenzációs mechanizmus részeként értelmezhetö; a szisztémás gyulladás kezdeti szakaszában az oxigénkereslet megemelkedik a fokozott anyagcsereráta következtében. A fokozott oxigénigény kielégítéséhez az oxigénszállítás is növekszik a CO emelkedésével, azonban a sejtek oxigenizációja nem javítható a megfelelően müködő mikrokeringés nélkül. A rossz kapilláris perfúzió nem teszi lehetővé az oxigénfelhasználást a látszólag emelkedett oxigénszállítás ellenére sem. Mindkét modell esetében a mikrokeringés jelentős károsodást szenvedett, amelyet a bélnyálkahártya csökkent RBCV-je jelzett. Ez azt jelenti, hogy a normális vagy emelkedett AMS-áramlás ellenére kimutatható mikrocirkulációs károsodás volt jelen a bélfalban. ${ }^{15} \mathrm{Az}$ AcPepA-val kezelt csoportoknál a vékonybélben mért RBCV szignifikánsan nagyobb volt. A jobb mikrokeringési paramétereket azonban nem emelke- 
dett CO- és AMS-áramlás mellett mértük, amely az oxigénfelhasználás javulását jelezheti. A C5a-gátló kezelés után mért alacsonyabb ET-1-értékek szintén hozzájárulhattak a mikrokeringés javulásához. A fokozott ET-1-felszabadulás fontos szerepet játszhat az intenzív gyulladásos válaszreakció kialakulásában, a komplementrendszer aktiválódása mellett. Az ET-1-felszabadulás, a kifejezett vasoconstrictor hatás miatt hozzájárul a mikrokeringés zavarához, valamint befolyásolja a citokinek felszabadulását is. ${ }^{16,19}$ Az AcPepA-val kezelt csoportnál a mikrokeringés javulása valószínűleg több tényezőn alapul, amelyhez a csökkent ET-1-felszabadulás és leukocytaaktiváció is hozzájárul.

Mind a sertésekben - a tamponádot követő korai szakaszban -, mind a patkányok esetében - az inzultust követő napon - magasabb HMGB-1-szinteket mértünk, amelyet az AcPepA-kezelés szignifikánsan csökkentett. A HMGB-1 fontos proinflammációs citokin, „alarmin”, amely hatékonyan aktiválja a neutrophil granulocytákat és citokintermelésüket fokozza. Eredményeink korrelálnak egy korábbi endotoxinsokk-modellben mért adatokkal, ahol az AcPepA-kezelés hatását vizsgálták. ${ }^{10}$ A korábban jelátvitelhez nem kapcsolt úgynevezett „,scavenging” C5a receptornak gondolt C5L2 receptorról a közelmúltban megjelent kutatások eredményei bizonyították, hogy fontos szerepe van a gyulladásos folyamatok kialakulásában és a komplement C5a rajta keresztül közvetlenül képes szabályozni a HMGB-1-kibocsátást. A C5L2 receptor jelentőségét mutatja, hogy a C5L2 gén kiütése egereknél nagyobb túlélési arányt eredményezett coecum ligatio-punctióval kiváltott szepszismodellben a vad típushoz képest. ${ }^{20}$

A fentieket összefoglalva, eredményeink azt igazolják, hogy a komplementrendszer korai aktivációja, ezen belül is a C5a fontos szerepet játszik a NOMI alatt bekövetkező szisztémás hemodinamikai és mikrokeringési zavar kialakulásában. A NOMI kezelési lehetőségei limitáltak, korai diagnózis esetén az egyetlen hatékony lehetőség az AMSbe juttatott vasodilatator kezelés, de a beavatkozás eredményességét a technikai és személyi feltételek korlátozzák. Az intravénásan alkalmazható C5a-gátló kezelés a gyulladásos folyamat mérséklése mellett hatékonyan befolyásolhatja a NOMI hemodinamikai következményeit is.

Támogatás: NKFI-116861; NKFIH-K116689; OTKAK104656; TÁMOP 4.2.4. A/2-11-1-2012-0001; GINOP2.3.2-15-2016-00015

\section{Irodalomjegyzék}

${ }^{1}$ Klar E, Rahmanian PB, Bücker A, et al.: Acute mesenteric ischemia: a vascular emergency. Dtsch Arztebl Int 2012; 109: 249-256

${ }^{2}$ Trompeter M, Brazda T, Remy CT, et al.: Non-occlusive mesenteric ischemia: etiology, diagnosis, and interventional therapy. Eur Radiol 2002; 12: 1179-1187

${ }^{3}$ Klotz S, Vestring T, Rötker J, et al.: Diagnosis and treatment of nonocclusive mesenteric ischemia after open heart surgery. Ann Thorac Surg 2001; 72: 1583-1586
${ }^{4}$ Ito BR, Engler RL, Balzo U, et al.: Role of cardiac mast cells in complement C5a-induced myocardial ischemia. American Journal of Physiology, Heart and Circulatory Physiology 1993; 264: H1346-H1354

${ }^{5}$ Lundberg C, Marceau F, Hugli TE: C5a-induced hemodynamic and hematologic changes in the rabbit. Role of cyclooxygenase products and polymorphonuclear leukocytes. Am J Pathol 1987; 128: 471-483

${ }^{6}$ Ehrengruber $M U$, Geiser T, Deranleau DA: Activation of human neutrophils by $\mathrm{C} 3 \mathrm{a}$ and $\mathrm{C} 5 \mathrm{~A}$ comparison of the effects on shape changes, chemotaxis, secretion, and respiratory burst. FEBS Letters 1994; 346: 181-184

${ }^{7}$ Sacks T, Moldow CF, Craddock PR, et al.: Oxygen radicals mediate endothelial cell damage by complement-stimulated granulocytes. An in vitro model of immune vascular damage. Journal of Clinical Investigation 1978; 61: 1161-1167

${ }^{8}$ Ember JA, Sanderson SD, Hugli TE, et al.: Induction of interleukin-8 synthesis from monocytes by human C5a anaphylatoxin. Am J Pathol 1994; 144: 393-403

${ }^{9}$ Fujita E, Farkas I, Campbell W, et al.: Inactivation of C5a anaphylatoxin by a peptide that is complementary to a region of C5a. J Immunol 2004; 172: 6382-6387

${ }^{10}$ Okada H, Imai M, Ono F, et al.: Novel complementary peptides to target molecules. Anticancer Res 2011; 31: 2511-2516

${ }^{11}$ Érces D, Nógrády M, Varga $G$, et al.: Complement C5a inhibition improves late hemodynamic and inflammatory changes in a rat model of nonocclusive mesenteric ischemia. Surgery 2016; 159: 960-971

12 Érces D, Nógrády M, Nagy E, et al.: Complement C5A antagonist treatment improves the acute circulatory and inflammatory consequences of experimental cardiac tamponade. Crit Care Med 2013; 41: e344-e351

13 Groner W, Winkelman JW, Harris AG, et al.: Orthogonal polarization spectral imaging: A new method for study of the microcirculation. Nat Med 1999; 5: 1209-1212

${ }^{14}$ Kuebler WM, Abels C, Schuerer L, et al.: Measurement of neutrophil content in brain and lung tissue by a modified myeloperoxidase assay. Int J Microcirc Clin Exp 1996; 16: 89-97

${ }^{15}$ Tao W, Zwischenberger JB, Nguyen TT, et al.: Gut mucosal ischemia during normothermic cardiopulmonary bypass results from blood flow redistribution and increased oxygen demand. The Journal of Thoracic and Cardiovascular Surgery 1995; 110: 819-828

${ }^{16}$ Boros M, Massberg S, Baranyi L, et al.: Endothelin 1 induces leukocyte adhesion in submucosal venules of the rat small intestine. Gastroenterology 1998; 114: 103-114

${ }^{17}$ Lüscher TF, Barton M: Endothelins and endothelin receptor antagonists therapeutic considerations for a novel class of cardiovascular drugs. Circulation 2000; 102: 2434-2440

18 Wolfárd A, Vangel R, Szalay L, et al.: Endothelin-A receptor antagonism improves small bowel graft perfusion and structure after ischemia and reperfusion. Transplantation 1999; 68: 1231-1238 
${ }^{19}$ Szabó A, Suki B, Csonka E, et al.: Flow motion in the intestinal villi during hemorrhagic shock: a new method to characterize the microcirculatory changes. Shock 2004; 21: $320-328$
${ }^{20}$ Rittirsch D, Flierl MA, Nadeau BA, et al.: Functional roles for C5a receptors in sepsis. Nat Med 2008; 14 : $551-557$ 